\title{
AUTOEXPLOTACIÓN POSMODERNA Y ESCLAVITUDES MODERNAS. REFLEXIONES EN TORNO A LA SUBJETIVIDAD NEOLIBERAL
}

\author{
Jorge Polo Blanco \\ Escuela Superior Politécnica del Litoral, Guayaquil \\ bttp://dx.doi.org/10.15304/ag.38.2.4562
}

\section{Resumen}

En el presente trabajo queremos mostrar la debilidad o, por ser más exactos, la parcialidad de ciertos análisis de la subjetividad neoliberal. Y lo haremos por cuanto desde ellos se suele contemplar el régimen laboral específico y propio de una minúscula parte de la población mundial como si fuera un régimen hegemónico y absolutamente global, cuando lo cierto es que ni siquiera en los países del Norte global es ampliamente mayoritario. Con ese gesto teórico, que además asume matices occidentalocéntricos, se oscurecen las formas de vida y los regímenes laborales de amplísimas geografías humanas del Sur (pero también del Norte) que en absoluto transcurren según los parámetros de dicha subjetividad. En ese sentido, son análisis que aciertan en su descripción de la subjetividad neoliberal, pero yerran sin embargo en el momento de universalizarla.

Palabras clave: subjetividad neoliberal, empresario de sí mismo, autoexplotación, posmodernidad, economía inmaterial.

\begin{abstract}
In this paper we wish to show the weakness or, to be more precise, the partiality of certain analyses of neoliberal subjectivity. We will do so since it is usually from their point of view that the labour system which is specific to and typical of a tiny portion of the world population is considered as if it were a hegemonic and all-encompassing system, when the truth is that not even in the countries of the Global North is it the widespread system of the majority. With this theoretical approach, which also takes on Western-centric nuances, the ways of life and labour systems of vast human geographies of the South (but also of the North), which do not all fall within the parameters of this subjectivity, are overshadowed.
\end{abstract}

Recibido: 18/01/2018. Aceptado: 24/01/2019. 
In this regard, the analyses are correct in their description of neoliberal subjectivity, but they are mistaken when it comes to attributing to it the character of universality.

Keywords: neoliberal subjectivity, entrepreneur of the self, self-exploitation, postmodernity, immaterial economy.

\section{Empresarios de sí mismos...sólo unos pocos}

Byung-Chul Han ha venido reflexionado de forma sugestiva sobre los diversos procesos de subjetivación neoliberal, esto es, sobre el específico modo de dominación del régimen neoliberal. Éste consiguió imponerse a través de ciertas mutaciones de hondo calado. "Hoy creemos que no somos un sujeto sometido, sino un proyecto libre que constantemente se replantea y se reinventa. Este tránsito del sujeto al proyecto va acompañado de la sensación de libertad. Pues bien, el propio proyecto se muestra como una figura de coacción, incluso como una forma eficiente de subjetivación y de

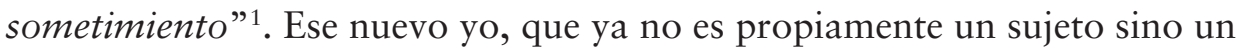
proyecto siempre abierto e indeterminado, y que precisamente por mostrar esa índole cree haberse liberado de todos los constreñimientos externos, se somete empero a las coacciones internas que imponen el "rendimiento y la optimización”, imperativos ineluctables de nuestra época. "El sujeto del rendimiento, que se pretende libre, es en realidad un esclavo. Es un esclavo absoluto, en la medida en que sin amo alguno se explota a sí mismo de forma voluntaria" ". El sindrome Burnout es un perfecto epítome de esa nueva situación; se trata, por decirlo así, de un giro inflexivo del discurso de Étienne de La Boétie, toda vez que hemos pasado de la "servidumbre voluntaria" a la autoexplotación voluntaria. Tenemos ante nosotros el inaudito espectáculo de unos organismos que se exprimen a sí mismos sin conmiseración.

Debemos resaltar, además, una circunstancia harto elocuente, y es que un sentimiento de goce ha sido implantado en estas subjetividades ultradinámicas, competitivas e hipercualificadas. En efecto, opera una peculiar euforia ante la perspectiva de un éxito que, siendo poco probable, espolea no obstante nuestro emprendimiento autoexplotador. "Impulsados por la esperanza de lograr la felicidad y el éxito, millones de jóvenes trabajadores altamente formados han aceptado trabajar en condiciones de un espantoso estrés, de sobreexplotación, incluso con salarios muy bajos, fascinados por

${ }^{1}$ Byung-Chul Han, Psicopolitica. Neoliberalismo y nuevas técnicas de poder, Barcelona, Herder, 2014, p. 11.

2 Ibíd. p. 12. 
una representación ambigua en la que el trabajador es descrito como un empresario de sí mismo y la competición es elevada a regla universal de la existencia humana" 3 . Este "cognitariado" posmoderno, sumido en un estado de precariedad permanente y flexibilidad ininterrumpida, constituye la vanguardia del nuevo ejército laboral de una economía cada vez más terciarizada, informacional y financiera. Esta cultura del alto rendimiento, que implica la perentoria necesidad de un reciclaje perpetuo y dosis inasequibles de autosuperación constante (toda vez que la estabilidad conformista es un terrible síntoma de fracaso), viene acompañada por un imperativo de gozar de la propia situación; quedan prohibidos el desánimo y el desaliento. Anteriormente, rendimiento y goce estaban separados; uno se exigía a sí mismo en el ámbito del trabajo para después gozar de la retribución y del tiempo libre. Eso es lo que ha cambiado, puesto que uno debe disfrutar con su auto-explotación, precisamente porque gracias a ese goce el rendimiento es todavía mayor ${ }^{4}$.

El régimen neoliberal, en su forma más tardía y ultramoderna, adquiere límites que sobrepasan la mera explotación por cuenta ajena. Muchísimo más eficiente que la explotación clásica (esto es, aquella forma en la que uno resulta explotado por un tercero) es la explotación de sí mismo por uno mismo; o la explotación de uno mismo por sí mismo, si se prefiere decir así. "El neoliberalismo, como una forma de mutación del capitalismo, convierte al trabajador en empresario. Fue el neoliberalismo, y no la revolución comunista, quien terminó por definir un régimen laboral en el cual la clase trabajadora no se encontraba ya sometida a la explotación ajena. Hoy cada uno es un trabajador que se explota a sí mismo en su propia empresa. Cada uno es amo y esclavo en una persona. También la lucha de clases se transforma en una lucha interna consigo mismo" 5 . La afirmación de Han, empero, nos parece exagerada y desajustada. Y es aquí donde comienza nuestra crítica. Porque es cierto que en numerosos sectores económicos de las naciones del Norte global (servicios, publicidad, finanzas) puede estar operando una mutación semejante; el "discurso empresarial", de hecho, incide con vehemencia en esa autoidentificación. Sin embargo, incluso en esas naciones del Norte existen todavía millones de asalariados y asalariadas

${ }^{3}$ Franco Berardi, La fábrica de la infelicidad. Nuevas formas de trabajo y movimiento global, Madrid, Traficantes de Sueños, 2003, p. 10.

${ }^{4}$ Christian Laval; Pierre Dardot, La nueva razón del mundo. Ensayo sobre la sociedad neoliberal, Barcelona, Gedisa, 2013, p. 360.

${ }^{5}$ Han, Psicopolítica, p. 17. 
cuya subjetividad se halla troquelada por los moldes de la vieja explotación. Por no hablar de las naciones del Sur global, donde la vieja producción industrial se asienta sobre niveles decimonónicos de explotación.

Han, sin embargo, lleva demasiado lejos su hiperbólica tesis de que "todos somos ya empresarios de nosotros mismos":

Ya no es posible sostener la distinción entre proletariado y burguesía (...) El régimen neoliberal transforma la explotación ajena en la autoexplotación que afecta a todas las «clases». La autoexplotación sin clases le es totalmente extraña a Marx. Ésta hace imposible la revolución social, que descansa en la distinción entre explotadores y explotados. Y por el aislamiento del sujeto de rendimiento, explotador de sí mismo, no se forma ningún nosotros político con capacidad para una acción común (...) Quien fracasa en la sociedad neoliberal del rendimiento se hace a sí mismo responsable y se avergüenza, en lugar de poner en duda a la sociedad o al sistema. En esto consiste la especial inteligencia del régimen neoliberal. ${ }^{6}$

Es curioso observar cómo este análisis converge en su diagnóstico con otros más conservadores, como el de Ralf Dahrendorf, que ya tiempo atrás había señalado que el marxismo erró con su teorema de la "ineluctable lucha de clases", toda vez que dicho antagonismo había por fin desaparecido o dejado de tener efecto en las sociedades contemporáneas ${ }^{7}$. Al resultar externamente ilocalizable el explotador ajeno, puesto que soy yo mismo el que me exploto a mí mismo, no cabe ningún tipo de resistencia colectiva y organizada. "En el régimen neoliberal de la autoexplotación uno dirige la agresión hacia sí mismo. Esta autoagresividad no convierte al explotado en revolucionario, sino en depresivo" 8 . En efecto, se trata de un régimen que nos impele a vivir y trabajar en un estado anímico de permanente positividad, sustentando a su vez una agitación nerviosa siempre creciente. Por ello, esta subjetivación produce inadaptados, deprimidos y fracasados; esto es, desecha a todos aquellos que no fueron capaces de aguantar el ritmo emocional exigido 9 . Porque los entornos laborales ya no son espacios de conflictividad antagónica, no hay en ellos rebeldías antijerárquicas o reivindicaciones con "conciencia de clase"; son recintos colaborativos y, en todo caso, uno debe aprender a "gestionar" (palabra fetiche) sus emociones para establecer con los compañeros y con los superiores una buena comunicación. El capitalismo tardío habría generado toda una "cultura de la afectividad", obteniendo dos notables efectos: la desactivación de la

${ }^{6}$ Ibíd. pp. 17-18.

${ }^{7}$ Ralf Dabrendorf, Las clases sociales y su conflicto en la sociedad industrial, Madrid, Rialp, 1962.

${ }^{8}$ Han, Psicopolitica, p. 18.

${ }_{9}^{9}$ Byung-Chul Han, La sociedad del cansancio, Barcelona, Herder, 2012. 
conflictividad laboral y, al mismo tiempo, la apropiación de los afectos como recurso explotable ${ }^{10}$.

El capitalismo contemporáneo, en cierto modo, se estaría desenvolviendo a través de una intensa "emocionalización" de las relaciones laborales; emotivismo en el ámbito productivo que, como veremos más adelante, operaría en consonancia con un potente emotivismo en el ámbito del consumo. Pero semejante análisis no parece dar cuenta de realidades sociales que todavía siguen siendo habituales e incluso mayoritarias. ¿O acaso las asalariadas que trabajan limpiando habitaciones de hotel, a dos euros por habitación, también pueden definirse como "empresarias de sí mismas"? $¿ Y$ una trabajadora del sector textil en Bangladesh, que cose ropa durante once horas al día por un sueldo miserable, también vive en un régimen de "autoexplotación"? ¿Podemos decir que semejantes asalariadas no están hiperexplotadas (por cuenta ajena), sino "emocionalmente deprimidas" por vivir en un régimen de autoexplotación continua? Ese diagnóstico nos parece apresurado y desenfocado, toda vez que contempla el régimen laboral de una minúscula parte de la población mundial y lo transforma en un régimen hegemónico, cuando ni siquiera en los países del Norte global es ampliamente mayoritario. La especificidad de un sector de la economía global se describe como una realidad preponderante, cuando no lo es en absoluto.

La gran movilización de las fuerzas laborales, a comienzos del siglo XIX, supuso una nueva puesta en acción del mundo del trabajo y una nueva codificación de los espacios productivos. El trabajo asalariado hubo de ser impuesto a través de múltiples intervenciones y reglamentaciones que regulaban los flujos de aprovisionamiento de mano de obra "libre" 11 . Porque la oferta de trabajo no siempre estuvo ahí, dispuesta para ser comprada y usada, como querrían ver los teóricos de la economía política clásica y neoclásica; esa fuerza de trabajo hubo de ser reclutada y puesta a funcionar a través de un determinado modo y en una determinada función social, y ello no se hizo sin violencia y sin múltiples resistencias de los así movilizados. El cuerpo hubo de ser disciplinado y convertido en una maquinaria viva de la que se extrae valor; como bien señaló Foucault, hubo de ser dispuesto y configurado únicamente como recurso del que extraer toda la

${ }^{10}$ Eva Illouz, Intimidades congeladas. Las emociones en el capitalismo, Buenos Aires, Katz, 2007.

${ }^{11}$ Yann Moulier-Boutang, De la esclavitud al trabajo asalariado. Economía histórica del trabajo asalariado embridado, Madrid, Akal, 2006. 
potencia, toda la energía, toda la fuerza aprovechable; cuerpos dóciles y útiles. Se trataba, pues, de una economización exhaustiva de todas las partículas de un cuerpo movilizado y dispuesto para obtener de él el máximo rendimiento productivo; un cuerpo, en suma, in-formado y constituido a través del eje docilidad-utilidad, despojado de todo excedente improductivo $^{12}$. La biopolítica disciplinaria, por lo tanto, convendría perfectamente a este régimen de producción. Y, en esto último, Han estaría muy de acuerdo con Foucault. Sin embargo, lo cierto es que aquél ha pretendido ir más allá del "poder disciplinario" analizado por el filósofo francés.

En cierto momento del siglo XX, se experimentó una crucial y singular transformación dentro de las sociedades capitalistas avanzadas, que se reflejó en múltiples desarrollos teóricos, por ejemplo en los trabajos de Schultz o Becker $^{13}$. Se trataba de aquella mutación de la que venimos hablando, esto es, de la conversión de todos los individuos en empresarios de sí mismos; el modelo empresarial se extendía como una metástasis imparable a todos y cada uno de los ámbitos de la realidad humana. Michel Foucault se acercaría con perspicacia a estos desarrollos en uno de sus cursos en el Collége de France, en 1979; allí señalaría que el neoliberalismo ya no operaba con la figura del homo oeconomicus clásico (modelo perteneciente al liberalismo decimonónico), sino que construía una nueva forma de subjetividad caracterizada por asumir e interiorizar un modelo puramente empresarial que podría describirse de la siguiente manera: yo mismo, como entidad física, psicológica y moral, me autoconcibo como una unidad productiva de la cual puedo (y debo) extraer un rendimiento económico siempre creciente ${ }^{14}$.

En un contexto semejante, y por ejemplificarlo, estudiar equivaldría a invertir en uno mismo, toda vez que esa ampliación de nuestros conocimientos incrementaría nuestras posibilidades de obtener de nosotros mismos un rendimiento mayor. "Ahora bien, ¿qué función tiene esa generalización de la forma «empresa»? Por un lado se trata, desde luego, de multiplicar el modelo económico, el modelo de la oferta y la demanda, el modelo de la inversión, el costo y el beneficio, para hacer de él un modelo de las relaciones

${ }^{12}$ Michel Foucault, Vigilar y castigar, Madrid, Siglo Veintiuno, 2000, p. 142.

${ }^{13}$ Theodore W. Schultz, Invirtiendo en la gente. La cualificación personal como motor económico, Barcelona, Ariel, 1985; Gary S. Becker, El capital humano. Un análisis teórico y empírico referido fundamentalmente a la educación, Madrid, Alianza, 1983.

${ }^{14}$ Pablo López Álvarez, "Biopolítica, liberalismo y neoliberalismo: acción política y gestión de la vida en el último Foucault”, en Arribas, S; Cano, G; Ugarte, J. (Coords.), Hacer vivir, dejar morir. Biopolitica y capitalismo, Madrid, CSIC/La Catarata, 2010, pp. 39-61. 
sociales, un modelo de la existencia misma, una forma de relación del individuo consigo mismo, con su entorno, el futuro, el grupo, la familia" ${ }^{15}$. La vida misma trasmuta en capital humano; mis capacidades intelectuales, emocionales y comunicativas son, todas ellas, otras tantas aptitudes capitalizables. Y entonces todo comportamiento humano debe quedar moldeado y prefigurado por unos mismos parámetros: el imperativo de la maximización permanente y la competitividad siempre ampliada. Hablamos no ya de un trabajo mercantilizado, fenómeno añejo, sino de la entera mercantilización de la existencia. Pero lo decisivo, para la cuestión que estamos tratando de dilucidar, es que se trata de un "modelo de relación consigo mismo". Foucault sí intuyó, por lo tanto, la nueva disposición de una tecnología del poder que ahora (en el orden neoliberal) trasmutaba en "tecnologías del yo", esto es, esa nueva situación por medio de la cual la dominación de unos individuos sobre otros adquiere la forma relativamente insólita de unos individuos que actúan sobre si mismos ${ }^{16}$. Pero, a juicio de Byung-Chul Han, dicha intuición foucaultiana no fue comprendida y desarrollada hasta sus últimas consecuencias. Foucault, en ese sentido, no habría podido ver que el régimen neoliberal de dominación terminó acaparando por completo la tecnología del yo $^{17}$.

El poder disciplinario moderno era básicamente negativo: quebraba resistencias, forzaba a la obediencia, inhibía, amenazaba, clasificaba, normativizaba, recluía, moldeaba, silenciaba, prohibía, censuraba e imponía (aunque, es cierto, semejante biopolítica también era productiva en tanto que generaba positivamente cuerpos dóciles y sometidos). Pero esta forma de poder era principalmente negativa, esto es, un compendio de violencias destinadas a doblegar, anular o en todo caso redireccionar el deseo y la voluntad: "A causa de su negatividad, el poder disciplinario no puede describir el régimen neoliberal (...) La técnica de poder propia del neoliberalismo adquiere una forma sutil, flexible, inteligente, y escapa a toda visibilidad. El sujeto sometido no es siquiera consciente de su sometimiento. El entramado

${ }^{15}$ Michel Foucault, Nacimiento de la biopolítica. Curso del Collége de France (19781979), Madrid, Akal, 2009, p. 239.

${ }^{16}$ Andrew Barry; Thomas Osborne y Nikolas Rose (Eds.), Foucault and political reason. Liberalism, neo-liberalism and rationalities of government, London, UCL Press, 1996; Paolo Virno, Gramática de la multitud. Para un análisis de las formas de vida contemporáneas, Madrid, Traficantes de Sueños, 2003; Santiago Castro-Gómez, Historia de la gubernamentalidad I. Razón de Estado, liberalismo y neoliberalismo en Michel Foucault, Bogotá, Siglo del Hombre, Pontificia Universidad Javeriana, Universidad Santo Tomás, 2015.

17 Han, Psicopolítica, p. 45. 
de dominación le queda totalmente oculto. De ahí que se presuma libre"18. La técnica de poder neoliberal no es áspera, sino amable y permisiva; es un poder más seductor que represor. "Ineficiente es el poder disciplinario que con gran esfuerzo encorseta a los hombres de forma violenta con preceptos y prohibiciones. Radicalmente más eficiente es la técnica de poder que cuida de que los hombres se sometan por si mismos al entramado de dominación" 19 . Pero ese poder amable y seductor es, por ello mismo, más poderoso; nos incita de forma risueña para que nosotros mismos decidamos alegremente sumergirnos en su bárbara dinámica de autoexplotación continua. Una dinámica que no contempla un espacio de descanso, que no permite una interrupción siquiera momentánea de la optimización perpetua de la propia personalidad. En este nuevo régimen, ya no existiría un hiato entre "tiempo laborable" y "tiempo vital ajeno a la eficiencia económica"; estaríamos todo el rato invirtiendo en nuestra propia optimización ${ }^{20}$.

Ese trabajador, que ya vive y actúa como un empresario de sí mismo, se apunta voluntariamente a cursos de coaching, a talleres de management personal y a seminarios de inteligencia emocional, en todos los cuales aprende a mejorar sus habilidades profesionales a través de una motivación creciente; es también el mundo de los manuales de autoayuda que nos enseñan a fortalecer nuestro liderazgo. Porque el objetivo es optimizar nuestras capacidades psíquicas, gestionar mejor nuestra comunicación, interiorizar una flexibilidad mental permanente, intensificar ilimitadamente nuestro rendimiento y fortalecer de manera continuada nuestra predisposición a la competitividad:

La ideología neoliberal de la optimización personal desarrolla caracteres religiosos, incluso fanáticos. Representa una nueva forma de subjetivación. El trabajo sin fin en el propio yo se asemeja a la introspección y al examen protestantes (...) En lugar de buscar pecados se buscan pensamientos negativos. El yo lucha consigo mismo como con un enemigo. Los predicadores evangélicos actúan hoy como mánagers y entrenadores motivacionales, y predican el nuevo evangelio del rendimiento y la optimización sin límite. ${ }^{21}$

Este "sujeto de rendimiento" no debe permitirse ningún momento de desánimo o de incredulidad, toda vez que tales estados anímicos menguarían su eficiencia. El imperativo de la permanente (e ininterrumpida) optimización personal ha sido completamente asimilado e interiorizado; y

\footnotetext{
${ }^{18}$ Ibíd. p. 28.

19 Ibíd.

${ }^{20}$ Jonathan Crary, 24/7. Capitalismo tardío y el fin del sueño, Barcelona, Ariel, 2015.

21 Han, Psicopolítica, p. 49.
} 
semejante proyecto debe ejecutarse siempre desde unos patrones emocionales frescos y risueños ${ }^{22}$

Y es por ello, señala de nuevo Han, que la analítica del poder foucaultiana ya no describe de manera correcta el mundo contemporáneo. Porque ya no hablamos de entornos rígidos de reclusión: cárceles, hospitales, escuelas o fábricas; ya no se trata de producir/moldear cuerpos, sino de configurar estados de ánimo y predisposiciones mentales. La biopolítica, entonces, debe dejar paso a la psicopolítica. Esta mutación se corresponde con un cambio en el régimen productivo: las disciplinas biopolíticas clásicas eran una minuciosa ortopedia destinada a la configuración de organismos bien ajustados a la producción maquínica, buscando una relación evidente entre docilidad y utilidad. Esta técnica de poder, por lo tanto, correspondía todavía a un régimen de explotación ajena: otros sometían mi cuerpo (lo codificaban y normativizaban de mil modos) para convertirlo en un cuerpo económicamente útil. "No obstante, la psique no está en el punto de mira del poder disciplinario. La técnica ortopédica del poder disciplinario es muy burda para penetrar en las capas profundas de la psique con sus anhelos ocultos, sus necesidades y su deseo, y acabar apoderándose de ellas" ${ }^{23}$. Esa biopolítica, por lo tanto, sería totalmente inadecuada al régimen de poder neoliberal, toda vez que éste tiene un carácter (y un objeto) más "psíquico" que "somático".

El neoliberalismo, en efecto, no encauza o entorpece el curso del deseo, sino que directamente lo produce; es un dispositivo que nos hace desear de un cierto modo. La biopolítica clásica - la foucaultiana-comprendía que la materialidad de nuestros deseos era todavía relativamente autónoma, y sólo ulteriormente las múltiples disciplinas del poder trabajaban sobre ese deseo (inhibiéndolo, reprimiéndolo, silenciándolo, normativizándolo, estigmatizándolo o clasificándolo a través de un minucioso y microfísico sometimiento de nuestra corporalidad viva). Pero el poder neoliberal ya no funciona así, sino que directamente se introduce en los rincones más íntimos de nuestra subjetividad para, desde allí, configurar la materialidad misma de nuestro deseo ${ }^{24}$. Por todo ello Byung-Chul Han le "reprocha" a Foucault no haber realizado el giro hacia la psicopolítica:

Este giro a la psique, y con ello a la psicopolítica, está relacionado con la forma de producción del capitalismo actual, puesto que este último está determinado por

${ }^{22}$ Barbara Ehrenreich, Sonríe o muere. La trampa del pensamiento positivo, Madrid, Turner, 2012.

${ }^{23}$ Han, Psicopolítica, p. 37.

${ }^{24}$ Jorge Alemán, Horizontes neoliberales en la subjetividad, Buenos Aires, Grama, 2016. 
formas de producción inmateriales e incorpóreas. No se producen objetos físicos, sino objetos no-físicos como informaciones y programas. El cuerpo como fuerza productiva ya no es tan central como en la sociedad disciplinaria biopolítica. Para incrementar la productividad, no se superan resistencias corporales, sino que se optimizan procesos psíquicos y mentales. El disciplinamiento corporal cede ante la optimización mental. ${ }^{25}$

Somos ahora sujetos de rendimiento, o empresarios de nosotros mismos, y nos autoexplotamos con avidez; logramos, además, que dicha dinámica de auto-sometimiento sea vivida e interpretada como un gesto de pura libertad. Esta forma de poder sería, desde luego, infinitamente más sibilina, sutil y eficaz que aquel viejo y grosero dispositivo disciplinario.

La sugerente propuesta de Han, una vez más, resulta muy pertinente... para una minúscula porción de la población trabajadora mundial; y además se fundamenta en el espejismo de considerar que la economía se ha tornado absolutamente informacional e inmaterial, como veremos en la siguiente sección ¿Ya no se producen cosas materiales? ¿Quién fabrica todo lo que consumimos? Porque lo cierto es que su análisis se circunscribe (he aquí la clave del asunto) a sociedades ultra-tecnológicas y posfordistas muy concretas, basadas en una economía pos-industrial de la información, la comunicación y el sector servicios. Pero la periferia del sistema-mundo capitalista sigue siendo muy dolorosamente "moderna", y sigue estando sujeta a un régimen de explotación (y saqueo) no muy diferente al de hace doscientos años. Debemos mostrar mucha prudencia con semejantes extrapolaciones, ciertamente exageradas, porque incluso habría algo de neocolonial en la postura del autor surcoreano afincado en Alemania, toda vez que los seres humanos que trabajan en las maquilas de México o en las fábricas de Bangladesh sufren una "tecnología de poder" muy disciplinaria y decimonónica; esos proletarios (mujeres jóvenes, principalmente) no son precisamente "oficinistas estresados" posmodernos y posfordistas (sufriendo el sindrome Burnout, auto-explotándose como enloquecidos empresarios de sí mismos en la City de Londres). Pensar que dicho modelo sirve para comprender el orden mundial es, en sí mismo, un gesto teórico colonial y occidentalocéntrico que ignora la actual división internacional del trabajo y las deslocalizaciones industriales de las que se sirven y nutren las economías terciarizadas e informacionales del primer mundo.

\footnotetext{
${ }^{25}$ Han, Psicopolítica, p. 42.
} 


\section{El espejismo de un capitalismo intangible y emocional}

En un mundo que ya es eminentemente ultraconsumista el viejo fetichismo de la mercancía alcanza un nuevo clímax, un paroxismo desmesurado, como ha señalado Slavoj Zizek. Merece la pena escuchar las palabras del pensador esloveno:

Esto, por supuesto, nos llevaría a reformular completamente el tópico común marxista de la «reificación» y el «fetichismo de la mercancía», en la medida en que este tema todavía descansa en la noción de fetiche como un objeto sólido cuya presencia estable ofusca la visión de su mediación social. Paradójicamente, el fetichismo alcanza su apogeo precisamente cuando el propio fetiche está «desmaterializado», convertido en una entidad virtual fluida e «inmaterial»; el fetichismo del dinero culminará con su pasaje a una forma electrónica, cuando los últimos rastros de su materialidad desaparezcan [...] Es sólo con esta «desmaterialización» completa, que la famosa vieja tesis de Marx del Manifiesto comunista, según la cual en el capitalismo «todo lo sólido se desvanece en el aire», adquiere un significado mucho más literal del que Marx tenía en mente, ya que no sólo nuestra realidad social material está dominada por el movimiento espectral/especulativo del Capital, sino que esta realidad misma se «espectraliza» progresivamente. ${ }^{26}$

Numerosos análisis han apuntado, por lo tanto, al surgimiento de un capitalismo cada vez más virtual, más intangible, más especulativo y, en definitiva, más postindustrial. Ahora veremos, empero, que no todos los seres humanos participan por igual de ese post.

También Jean Baudrillard, con su tono siempre hiperbólico, postulaba una suerte de posteconomía, esto es, el advenimiento de una era en la que la ciencia económica iba dejando de tener un objeto asible; un mundo en el que "la economía política se extingue bajo nuestros ojos, convirtiéndose por sí misma en una transeconomía de la especulación que se mofa de su propia lógica $[. .$.$] y que, por tanto, no tiene ya nada de económico ni de po-$ lítico. Un puro juego de reglas flotantes y arbitrarias, un juego de catástrofe. La economía política habrá, pues, llegado a su fin, aunque en modo alguno como se esperaba, sino de forma harto singular: exacerbándose hasta la parodia. La especulación ya no es la plusvalía, es el más-que-valor, es el éxtasis del valor, sin referencia a la producción ni a sus condiciones reales. Es la forma pura (y vacía), la forma expurgada de valor, que ya sólo apuesta por su propia revolución (su propia circulación orbital)"27. Habríamos entrado, al parecer, en un nuevo paradigma socioeconómico definido por

26 Slavoj Zizek, A propósito de Lenin. Política y subjetividad en el capitalismo tardio, Buenos Aires, Atuel, Parusía, 2004, p. 124.

${ }^{27}$ Jean Baudrillard, Pantalla total, Barcelona, Anagrama, 2000, p. 35. 
un régimen insólito de producción de valor. La característica distintiva del "viejo" capitalismo moderno era, ante todo, la expropiación de la tierra y del trabajo; arrancados de su raigambre familiar, comunal o artesanal, ambos elementos habían sido introducidos (violentamente) en un mercado formador de precios, convirtiéndolos en una mercancía más ${ }^{28}$. Pero la mercantilización estaba limitada en el tiempo y en el espacio; segmentos enteros de la vida de los hombres permanecían ajenos a la compraventa mercantil. Sin embargo, en esta nueva economía del ciberespacio todo viene quedando sumergido en el huracán omnímodo de la comercialización. "El espectáculo es el momento en el cual la mercancía alcanza la ocupación total de la vida social. No es únicamente que se haga patente la relación con la mercancía, sino que ya no hay otra cosa más que esa relación: el mundo visible es su mundo. La producción económica moderna amplía su dictadura tanto en extensión como en intensidad [...] En este punto de la «segunda revolución industrial», el consumo alienado se convierte en un deber para las masas, un deber añadido al de la producción alienada" ${ }^{29}$. En este contexto, en efecto, el consumo se convierte en un horizonte último y en un marco de comprensión interiorizado por todos, incluso por aquéllos que apenas alcanzan los "valores de uso" imprescindibles para la supervivencia. Y es cierto que el consumo, como estilo de vida y como aspiración existencial, se ha instalado también en buena parte de la población mundial (incluidas, en cierto modo y grado, las masas populares de las naciones llamadas "subdesarrolladas"). Es verdad, por lo tanto, que el neoliberalismo también ha colonizado en buena medida el deseo de los sectores más humildes y empobrecidos de las naciones periféricas; muchos jóvenes que malviven en suburbios miserables sueñan con adquirir un Smartphone de última generación, cuando en su barrio ni siquiera hay sistema de alcantarillado, agua potable o un centro médico decente.

En el Occidente "avanzado" y posmoderno, según se desprende de algunos análisis, seríamos ya algo parecido a "consumidores de signos", esto es, individuos que habitarían una economía hipersimbólica y altamente semiotizada compuesta por un ingente, penetrante y seductor universo de marcas, imágenes, significados, iconos y logotipos. Se habría ido gestando, señalan muchos analistas, una forma inédita de capitalismo, "la nueva era del

${ }^{28}$ Karl Polanyi, La gran transformación. Los orígenes politicos y económicos de nuestro tiempo, México, Fondo de Cultura Económica, 2003.

${ }^{29}$ Guy Debord, La sociedad del espectáculo, Valencia, Pre-textos, 2003, p. 55. 
capitalismo cultural" ${ }^{30}$, distinta en algún sentido al viejo capitalismo industrial. "En una economía global progresivamente dominada por una red electrónica de comercio y comunicaciones, asegurarse el acceso a las propias experiencias de vida se vuelve tan importante como lo fue el ser propietario en la era dominada por la producción de bienes industriales" 31 . La producción se desmaterializa, pues ahora se trataría cada vez más de ofrecer no tanto objetos como "experiencias" para los clientes que las consumen; lo que éstos adquieren (ilusoriamente, claro) son "vivencias únicas e irrepetibles"; y decimos ilusoriamente porque en verdad dichas vivencias son ofrecidas de manera estandarizada. Pero estaríamos, en cualquier caso, en el umbral de una suerte de capitalismo emocional en el que los consumidores querrían, ante todo, "saborear sensaciones".

Como bien apunta Zizek, se habría producido una suerte de inversión: el objeto o producto, que antaño representaba la finalidad de nuestro deseo, ahora sería un mero vehículo para obtener una experiencia, una vivencia, una emoción; éstas serían ahora el verdadero objeto de nuestro deseo. Es decir, compramos un producto porque encarna un determinado contenido simbólico, un determinado valor intangible, un estilo de vida; y sería esto último lo que verdaderamente estaría circulando por los escaparates de nuestro nuevo capitalismo. "Lo que se estaría verificando hoy, el rasgo definitorio del capitalismo "postmoderno", es la mercantilización directa de la experiencia misma: lo que se está comprando en el mercado son cada vez menos productos (objetos materiales) para poseer, y cada vez más experiencias vitales- experiencias de sexo, comida, comunicación, consumo cultural, participación en un estilo de vida" 32 . De lo que se trata, en suma, es de que nos estamos convirtiendo en consumidores de nuestra propia vida, pues "ya no compramos los objetos, finalmente compramos (el tiempo de) nuestra vida" 33 . Encontramos, por lo tanto, un consumidor voluble que demanda y consume no ya objetos materiales externos, sino experiencias que lo constituyen. Se compra a sí mismo, pues compra las experiencias que en cada momento lo determinan; hoy unas, mañana otras, pues la oferta es amplísima y variada. Compramos e ingerimos ese conjunto de valores intangibles que diseñan y gestionan los ingenieros de la mercadotecnia; erotizados por esos signos que saturan nuestros escaparates, nos sumergimos en

${ }^{30}$ Jeremy Rifkin, La era del acceso. La revolución de la nueva economía, Barcelona, Paidós, 2000, p. 187.

${ }^{31}$ Ibíd. p. 188.

${ }^{32}$ Zizek, op. cit., p. 122.

${ }^{33}$ Ibíd. p. 123. 
una hechizante y fetichista puesta en escena que nos presenta el artículo de consumo como vía de acceso a un mundo pletórico de sensaciones prometedoramente excitantes. "El carácter físico de la economía se reduce. Si la era industrial se caracterizaba por la acumulación de capital y de propiedad física, en la nueva era lo estimable son las formas intangibles de poder que se presentan en paquetes de información y en activos intelectuales. El hecho es que se avanza en la desmaterialización de los productos físicos que durante largo tiempo fueron la medida de la riqueza en el mundo industrial" 34 . Nos hallaríamos, en definitiva, ante una economía fantasmática repleta de sensaciones, deseos, emociones y experiencias afectivas.

Sin embargo, no debemos caer en la ilusión de pretender que tras la rutilante seducción permanente del capitalismo consumista no han existido siempre unos márgenes del sistema (muy amplios, por cierto) donde se encuentran los perdedores del juego, esos "consumidores defectuosos" de los que hablaba Zygmunt Bauman ${ }^{35}$; esto es, todos aquellos sectores de la población que no pueden acceder al eterno reclamo de una oferta de consumo cuya obtención, casi siempre frustrada, se convierte en una quiebra de sentido vivencial. Estas franjas sociales, donde se ubican los perdedores del juego, son extraordinariamente amplias también en el interior de las sociedades capitalistas centrales; hablamos de sectores populares cuya subjetividad, es cierto, ha quedado troquelada o prefigurada por los códigos vigentes en la era del ultraconsumismo, y cuya precaria situación socioeconómica los hace girar en una dinámica psicosocial de permanente insatisfacción. Son chicos y chicas que, viviendo en condiciones de marginalidad, han conformado su subjetividad (y su horizonte existencial) a través del código hiperconsumista; pero, y es aquí donde queríamos arribar, no podemos perder de vista su situación de objetiva exclusión social. Eso, por el lado del consumo; pero, si fijamos ahora nuestro foco en el oscurecido lado de la producción, tampoco debemos incurrir en un espejismo que nos pueda hacer creer que los viejos resortes de la explotación laboral ya no existen.

En efecto, esa economía altamente especulativa, financiera, anárquica y flotante que circula a la velocidad de la luz por encima de nuestras cabezas en una red cuasi-incontrolable y atmosférica, esa economía que parece perder toda referencia a un objeto susceptible de ser estudiado y analizado, sigue teniendo, no obstante, una materialidad localizable. Una vez más, conviene prestar atención a las palabras de Slavoj Zizek:

${ }^{34}$ Rifkin, op. cit., p. 49.

${ }^{35}$ Zygmunt Bauman, La posmodernidad y sus descontentos, Madrid, Akal, 2001, p. 57. 
Lo que caracteriza al «capitalismo tardío» es la escisión entre la producción de experiencias culturales como tales y su base material (parcialmente invisible), entre el Espectáculo (de experiencia teátrica) y sus mecanismos secretos de puesta en escena. En la percepción ideológica del Primer Mundo de hoy, el trabajo mismo (la labor manual en tanto opuesta a la actividad de producción cultural «simbólica»), y no el sexo, aparece como el sitio de indecencia obscena a ser ocultado del ojo público. Una tradición que se remonta al Rheingold de Wagner y a Metrópolis de Lang, tradición en la que el proceso productivo tiene lugar bajo tierra, en cuevas oscuras, hoy culmina en la «invisibilidad» e los millones de obreros anónimos que trabajan en condiciones infrahumanas en las fábricas del Tercer Mundo desde los Gulags chinos o indonesios hasta las líneas de ensamble en Brasil -Occidente puede permitirse el lujo de hablar de «la clase obrera en desaparición» $[\ldots] .{ }^{36}$

En el juego de la economía virtual postmoderna sigue habiendo perdedores, excluidos y explotados; el "juego ficticio" del capitalismo especulativo sigue cobrándose sus víctimas terrenales. La producción real, material y tangible (nada posmoderna, podríamos decir, sino dolorosamente moderna) se traslada a la periferia de Occidente, a esos países subdesarrollados donde se instalan las fábricas más inhumanas que producen en las condiciones más terroríficas y alienantes los productos tangibles que, ulteriormente, serán gestionados por las compañías que los venden aquí, en los países desarrollados, revestidos ya de todo el hechizo simbólico de la marca. Las grandes empresas han ido entregando la producción material, la manufactura clásica, a otras empresas subcontratadas en esa periferia mientras que ellas, he aquí todo el secreto del asunto, se han quedado con la gestión fetichista de la marca. Este proceso ha sido definido o descrito como "posmodernización económica" ${ }^{37}$. Pero no debemos olvidar que esos gigantescos entramados de subcontratación, que proveen nuestra materialidad económica, se sostienen en durísimos regímenes laborales que rozan (y a veces alcanzan) la semiesclavitud. Y no hacerse cargo de esta geografía de la explotación, embaucándonos con los sortilegios analíticos de un capitalismo emocional y semiótico, engendraría una actitud teórica de complicidad con el aspecto más criminal del sistema económico global.

\section{El espejismo de una economía inmaterial}

Puede llegar a insinuarse, y así lo hizo Baudrillard, que la teorización marxista ya no sirve para dar cuenta de esta "nueva mutación" de la sociedad capitalista. "Algo ha cambiado radicalmente en la esfera capitalista,

${ }^{36}$ Zizek, op. cit., p. 125.

${ }^{37}$ Michael Hardt y Antonio Negri, Imperio, Barcelona, Paidós, 2002, p. 261. 
algo a lo que el análisis marxista ya no responde" 38 . En efecto, "la fase propiamente capitalista de socialización forzada por el trabajo, de movilización intensiva de las fuerzas productivas, ha pasado" ${ }^{39}$. En la esfera del valor de cambio han ido entrando aspectos no ligados directamente a la fuerza de trabajo, dimensiones en principio inalienables, tales como el lenguaje, los afectos o nuestra capacidad de generar lazos de amistad. En un contexto semejante, "el centro de gravedad se ha desplazado: el epicentro del sistema contemporáneo ya no es el proceso de producción material" ${ }^{40}$. La equivalencia mercantil ha colonizado y fagocitado dentro de su interioridad todo ese ámbito que un cierto marxismo vulgar siempre situaba en los "reflejos" de la superestructura. Pero semejante proceso ya no puede ser analizado, entiende Baudrillard, con el armazón teórico y conceptual del marxismo tradicional; de nada sirven ya los viejos términos adscritos al universo de la economía política clásica: modo de producción, fuerzas productivas, relaciones de producción, plusvalía, clase social, lucha de clases, etc. La explicación marxista, al parecer, habría quedado obsoleta. En las nuevas sociedades del hiperconsumo es el objeto-signo, y no ya la clásica mercancía, quien ocupa la centralidad de la circulación social.

David Harvey, empero, respondió polémicamente a Baudrillard, en lo tocante a esa presunta emergencia de un capitalismo semiótico:

Este fenómeno ha llevado a Baudrillard a sostener que el análisis de la producción de mercancías de Marx está pasado de moda porque hoy el capitalismo se dedica sobre todo a la producción de signos, imágenes y sistemas de signos y no a las mercancías en sí mismas. La transición que señala Baudrillard es importante, aunque en realidad no es difícil extender la teoría de la producción de mercancías de Marx para explicar este fenómeno [...] Si se tienen en cuenta las presiones para acelerar el tiempo de rotación (y superar las barreras espaciales), la mercantilización de las imágenes de tipo más efímero parecería ser una bendición divina desde el punto de vista de la acumulación del capital $[\ldots] .^{41}$

En ese sentido, advierte Harvey que la teoría marxista podría seguir haciéndose cargo de las mutaciones desarrolladas por el capitalismo contemporáneo; pero no es éste el objeto de nuestro trabajo. Lo interesante es destacar ese espejismo en el que incurren muchos análisis, como el de

38 Jean Baudrillard, El espejo de la producción o la ilusión crítica del materialismo histórico, Barcelona, Gedisa, 2000, p. 126.

${ }^{39}$ Ibíd. p. 140.

${ }^{40}$ Ibíd. p. 139.

${ }^{41}$ David Harvey, La condición de la posmodernidad. Investigación sobre los orígenes del cambio cultural, Buenos Aires, Amorrortu, 1998, p. 318. 
Baudrillard, consistente en la postulación de algún tipo de transición a una economía desmaterializada.

¿Tiene el ethos posmoderno algo que ver con todo lo aquí expuesto? La cultura posmoderna se alimenta de esa situación socioeconómica y cultural, nace de ella. Terry Eagleton estableció la insinuada conexión de una manera muy acertada ${ }^{42}$. Y ya sabemos qué nueva fase del capitalismo es la que se desplegó y articuló como matriz material de esa transición hacia una cultura posmoderna. Se trataría, en efecto, de aquel capitalismo postfordista cuyo centro de gravedad basculó de manera significativa desde la producción industrial clásica hacia la industria de servicios y hacia las tecnologías de la información; ese capitalismo postfordista que, finalmente, terminará volcándose en unos incontrolables y descentralizados flujos financieros que presentan un carácter extremadamente especulativo y, aparentemente, cada vez más desligado de la economía productiva "real". Un capitalismo, asimismo, que lejos de ejercitar ya el consumo rígido y estandarizado de la producción en serie se adentra en una nueva fase de ultra-consumismo hedonista, ecléctico, libidinoso, juguetón e hiperdiversificado, que encuentra en el simulacro y en el espectáculo, en la imagen-mercancía, el nuevo epicentro de un vasto fetichismo. Y, al parecer, el "estilo de pensamiento" posmoderno se incardina en ese nuevo ciclo de la economía-mundo capitalista" 43 . Porque, como bien señaló Fredric Jameson, la posmodernidad aparece como la lógica cultural del capitalismo tardío $0^{44}$.

Ha llegado a sostenerse que la conflictividad social, en un contexto semejante, tendría que ver principalmente con los problemas de "adaptación” de unos organismos humanos que no estarían preparados para amoldarse a un entorno que se habría tornado hipercomplejo y exigente; un entorno en el que circulan a demasiada velocidad toneladas de información, como un torrente imposible de asimilar o digerir; se fraguarían, de tal modo, conciencias inestables que se verían saturadas, desbordadas y crecientemente desquiciadas. Esos serían los nuevos problemas de la "economía psíquica”, según nos quería advertir Alvin Toffler. "El «shock» del futuro es la respuesta a un estímulo excesivo. Se produce cuando el individuo se ve obligado a actuar por encima de su nivel de adaptación" 45 . En esa miríada inabarcable de sobre-información, en esa abundancia de símbolos mercantiles,

${ }^{42}$ Terry Eagleton, Las ilusiones del posmodernismo, Buenos Aires, Paidós, 1997, p. 11.

${ }^{43}$ Harvey, op. cit., p. 180.

${ }^{44}$ Fredric Jameson, "Posmodernismo y sociedad de consumo", en La posmodernidad, Barcelona, Kairós, 1985, pp. 165-186.

${ }^{45}$ Alvin Toffler, El "shock" del futuro, Barcelona, Plaza \& Janes, 1973, p. 360. 
en esa orgía de "experiencias" y "estilos de vida” que se compran y venden en un mercado omnímodo, el individuo se fragmenta en múltiples pseudoidentificaciones blandas. Ya no se pertenece a una clase social (y, por lo mismo, se habrían volatilizado los antagonismos estructurales), sino a un "estilo de vida" intercambiable del que se prescinde rápidamente para obtener otro; la plasticidad y la fluidez constituyen a este sujeto desquiciado y saturado de información. La vieja teoría crítica ya no podría hacerse cargo de esta nueva realidad, porque el problema ya no sería la alienación del sujeto (éste, de hecho, habría muerto) sino la fragmentación esquizoide. Cuando la economía se transfigura en relaciones inmateriales e intangibles, desaparecen al mismo tiempo los conflictos materiales que tienen que ver con la objetividad de la precariedad laboral, la explotación, el empobrecimiento y la marginación social. Sin embargo, nosotros sostenemos que la premisa principal es ilusoria. Se han de contemplar las múltiples mutaciones internas que ha sufrido el capitalismo en las últimas décadas, desde luego; pero, y aun reconociendo que los análisis de dichas mutaciones ofrecen perspectivas interesantes, no podemos olvidar que las sociedades capitalistas se siguen fundamentando en férreas relaciones de explotación y dominio. Es evidente que el capitalismo postfordista y ultraconsumista produjo transformaciones en la subjetividad hegemónica, como vimos en la primera sección de este trabajo, pero no por ello desapareció la objetividad estructural de un sistema fundamentado en la exclusión y en la desigualdad.

Es cierto, como ha resaltado Bauman, que el capital global se ha desatado de sus antiguos asideros clásicos, desterritorializándose, y se ha tornado más flexible y volátil:

El propio capital, en otro tiempo atado al acero y al hormigón, a los sólidos edificios fabriles y a la maquinaria pesada, se ha convertido ya en la encarnación de la flexibilidad; se ha hecho un maestro en el arte de sacarse a sí mismo, cual conejo, del sombrero o desaparecer sin dejar rastro, desempeñando la superautopista de la información el papel de varita mágica. No obstante, puesto que lo que a algunos cura a otros mata, las transformaciones que suponen racionalización y flexibilidad para el capital repercuten sobre la castigada retaguardia como catástrofes, como acontecimientos inexplicables, como algo que escapa al poder humano. ${ }^{46}$

El nuevo capital hiperflexible sobrevuela la geografía humana haciendo blanco ora aquí, ora allá, movilizándose con suma labilidad, des-anclándose fácilmente cuando ya no obtiene el máximo rendimiento para desplazarse velozmente a otros territorios; la dinámica de este capitalismo escapa a todo control político-social, y sus prebendas y golpes advienen cual catástrofes

${ }^{46}$ Bauman, op. cit., p. 50. 
ecológicas o climatológicas, sustrayéndose a toda normatividad restrictiva. En un contexto semejante, el trabajo también queda absolutamente flexibilizado, y su precariedad y fragilidad hacen que la incertidumbre sea un ingrediente consustancial de la vida del trabajador; éste, desprotegido ante las veleidades de un capital sumamente liberado, apenas puede tejer un proyecto de vida estable en torno a un trabajo permanente ${ }^{47}$. La entera vida social y cultural se ve sumida en la fragmentación, en la incertidumbre crónica, en la inseguridad permanente, en la renovación y el reciclaje sempiternos. Y los nuevos discursos de la "gestión empresarial", desde luego, abundaron con mucha intensidad en ese lenguaje $\mathrm{e}^{48}$. Pero, y este pero es precisamente el objeto de nuestro estudio, ello no puede hacernos olvidar que en muchos lugares del mundo se encuentra anclada la producción material; en la trastienda de la economía inmaterial posmoderna encontramos inmensas geografías repletas de economía material, en la que cientos de millones de seres humanos son vorazmente explotados.

\section{A modo de conclusión}

La subjetividad neoliberal, esa misma que nos convierte en "empresarios de nosotros mismos" espoleados por una autoexplotación inmisericorde, sin duda ha ocupado un lugar preponderante en ciertas regiones de la economía-mundo capitalista; pero, como señalamos en la primera sección del trabajo, semejante subjetivación afecta a una parte relativamente pequeña de la población trabajadora mundial: aquella que tiene vínculos con los nódulos más vanguardistas de la economía global. Es evidente que la subjetividad neoliberal va cobrando vigor, y paulatinamente se extiende a los sectores medios de los países centrales. Incluso los sectores populares adquieren componentes de tal subjetividad, hasta el punto de compartir las aspiraciones de las élites o autoconcebirse no como "pobres", sino como "perdedores", "inadaptados" y "fracasados". Pero pretender que esa subjetividad neoliberal, fundamentada en la autoexplotación, se ha tornado absolutamente hegemónica implica desconocer las inmensas regiones del mundo donde sigue operando un régimen de explotación dolorosamente clásico, terriblemente decimonónico.

${ }^{47}$ Richard Sennett, La corrosión del carácter. Las consecuencias personales del trabajo en el nuevo capitalismo, Barcelona, Anagrama, 2013.

${ }^{48}$ Luc Boltanski y Ève Chiapello, El nuevo espíritu del capitalismo, Madrid, Akal, 2002. 
De igual modo, postular el advenimiento pleno de una economía inmaterial, sostenida en un capitalismo emocional o semiótico, implica sucumbir a otro espejismo teórico. Porque, en efecto, para que amplias capas de población de los países centrales (o las élites de los países periféricos) puedan "saborear las sensaciones" y "vivir las experiencias" que ofrece el capitalismo hiperconsumista, otros seres humanos (en los países periféricos, principalmente) deben trabajar como bestias en regímenes de verdadera semiesclavitud. Hemos deslocalizado la producción material, para creer ilusoriamente que nuestra economía se ha tornado intangible e inmaterial. Sin olvidar, por supuesto, que incluso dentro de los países avanzados (en el Centro del sistema-mundo) también existen millones de seres humanos que malviven en condiciones de explotación y que no pueden acceder a los suculentos y rutilantes reclamos del capitalismo emocional.

\section{Bibliografía}

Alemán, Jorge, Horizontes neoliberales en la subjetividad, Grama, Buenos Aires, 2016.

Barry, Andrew; Osborne, Thomas; Rose, Nikolas (Eds.), Foucault and political reason. Liberalism, neo-liberalism and rationalities of government, UCL Press, London, 1996.

Baudrillard, Jean, Pantalla total, Anagrama, Barcelona, 2000.

Baudrillard, Jean, El espejo de la producción o la ilusión crítica del materialismo histórico, Gedisa, Barcelona, 2000.

Bauman, Zygmunt, La posmodernidad y sus descontentos, Akal, Madrid, 2001. Becker, Gary S., El capital humano. Un análisis teórico y empírico referido fundamentalmente a la educación, Alianza, Madrid, 1983.

Berardi, Franco, La fábrica de la infelicidad. Nuevas formas de trabajo y movimiento global, Traficantes de Sueños, Madrid, 2003.

Boltanski, Luc; Chiapello, Ève, El nuevo espíritu del capitalismo, Akal, Madrid, 2002.

Castro-Gómez, Santiago, Historia de la gubernamentalidad I. Razón de Estado, liberalismo y neoliberalismo en Michel Foucault, Siglo del Hombre, Pontificia Universidad Javeriana, Universidad Santo Tomás, Bogotá, 2015.

Crary, Jonathan, 24/7. Capitalismo tardío y el fin del sueño, Ariel, Barcelona, 2015.

Dahrendorf, Ralf, Las clases sociales y su conflicto en la sociedad industrial, Rialp, Madrid, 1962. 
Debord, Guy, La sociedad del espectáculo, Pre-textos, Valencia, 2003.

Eagleton, Terry, Las ilusiones del posmodernismo, Paidós, Buenos Aires, 1997.

Ehrenreich, Barbara, Sonríe o muere. La trampa del pensamiento positivo, Turner, Madrid, 2012.

Foucault, Michel, Vigilar y castigar, Siglo Veintiuno, Madrid, 2000.

Foucault, Michel, Nacimiento de la biopolítica. Curso del Collége de France (1978-1979), Akal, Madrid, 2009.

Han, Byung-Chul, La sociedad del cansancio, Herder, Barcelona, 2012.

Han, Byung-Chul, Psicopolítica. Neoliberalismo y nuevas técnicas de poder, Herder, Barcelona, 2014.

Hardt, Michael; Negri, Antonio, Imperio, Paidós, Barcelona, 2002,

Harvey, David, La condición de la posmodernidad. Investigación sobre los orígenes del cambio cultural, Amorrortu, Buenos Aires, 1998.

Illouz, Eva, Intimidades congeladas. Las emociones en el capitalismo, Katz, Buenos Aires, 2007.

Jameson, Fredric, "Posmodernismo y sociedad de consumo", en La posmodernidad, Kairós, Barcelona, 1985, 165-186.

Laval, Christian; Dardot, Pierre, La nueva razón del mundo. Ensayo sobre la sociedad neoliberal, Gedisa, Barcelona, 2013, p. 360.

López Álvarez, Pablo, "Biopolítica, liberalismo y neoliberalismo: acción política y gestión de la vida en el último Foucault”, en Arribas, S; Cano, G; Ugarte, J. (Coords.), Hacer vivir, dejar morir. Biopolitica y capitalismo, CSIC/La Catarata, Madrid, 2010, pp. 39-61.

Moulier-Boutang, Yann, De la esclavitud al trabajo asalariado. Economía histórica del trabajo asalariado embridado, Akal, Madrid, 2006.

Polanyi, Karl, La gran transformación. Los orígenes políticos y económicos de nuestro tiempo, Fondo de Cultura Económica, México, 2003.

Rifkin, Jeremy, La era del acceso. La revolución de la nueva economía, Paidós, Barcelona, 2000.

Schultz, Theodore W., Invirtiendo en la gente. La cualificación personal como motor económico, Ariel, Barcelona, 1985.

Sennett, Richard, La corrosión del carácter. Las consecuencias personales del trabajo en el nuevo capitalismo, Anagrama, Barcelona, 2013.

Toffler, Alvin, El "shock" del futuro, Plaza \& Janes, Barcelona, 1973.

Virno, Paolo, Gramática de la multitud. Para un análisis de las formas de vida contemporáneas, Traficantes de Sueños, Madrid, 2003.

Zizek, Slavoj, A propósito de Lenin. Política y subjetividad en el capitalismo tardio, Atuel, Parusía, Buenos Aires, 2004. 